\title{
Decapod crustaceans from the lower Miocene Qom Formation of the Isfahan area, Central Iran
}

\author{
Crustáceos decápodos de la Formación Qom del Mioceno inferior en el área de Isfahan, \\ Irán central
}

\author{
Matúš Hyžný1,*, Ali Bahrami ${ }^{2}$, Mehdi Yazdi², Hossein Torabi ${ }^{2}$
}

'Department of Geology and Palaeontology, Faculty of Natural Sciences, Comenius University, Ilkovičova 6, 842 15, Bratislava, Slovakia.

${ }^{2}$ Department of Geology, Faculty of Sciences, University of Isfahan, 81746, Isfahan, Iran.

* Corresponding author: (M. Hyžný) hyzny.matus@gmail.com

How to cite this article:

Hyžný, M., Bahrami, A., Yazdi, M., Torabi, H., 2021, Decapod crustaceans from the lower Miocene Qom Formation of the Isfahan area, Central Iran: Boletín de la Sociedad Geológica Mexicana, 73 (3), A140521. http://dx.doi. org/10.18268/BSGM2021v73n3al40521

Manuscript received: April 22, 2021

Corrected manuscript received: May 2, 2021

Manuscript accepted: May 7, 2021

Peer Reviewing under the responsibility of Universidad Nacional Autónoma de México.

This is an open access article under the CC BY-NC-SA license(https://creativecommons.org/licenses/by-nc-sa/4.0/)

\begin{abstract}
From the lower Miocene (Burdigalian) of the Qom Formation, exposed in three sections (Kuh-e-Donbeh, Bagher-Abad, and Vartun) in Central Iran, a decapod crustacean assemblage is described. The specimens exhibit two modes of preservation: carapaces (either isolated or with attached appendages) and isolated cheliped elements. All studied specimens are fractured and/or eroded. Based on this moderately preserved material, three brachyuran crab taxa are identified, including Mursia cf. lienharti (Bachmayer, 1962), Palaeocarpilius rugifer Stoliczka, 1871, and Necronectes sp. The occurrence of $P$. rugifer represents the youngest confirmed occurrence of the species, whereas other two taxa represent the first confirmed Iranian occurrences of respective genera. This report enriches our knowledge on Miocene decapod assemblages of Iran, and thus helping to better understand the decapod migratory patterns along the Tethyan Seaway.
\end{abstract}

Keywords: Brachyura, early Miocene, Qom Formation, Isfahan, Gentral Iran.

\section{RESUMEN}

Se describe un conjunto de crustáceos decápodos correspondientes a la Formación Quom del Mioceno inferior (Burdigaliano) en tres regiones de Irán central (Kuh-e-Donbeh, Bagher-Abad y Vartun). Los especimenes exponen dos modos de preservación: caparazones ya sea aislados o con apéndices adheridos) y elementos aislados quelípedos. Todos los ejemplares aqui estudiados están fracturados o erosionados. Con base en este material moderadamente conservado, se identificaron tres taxones de cangrejos braquiuros incluyendo Mursia cf. lienharti (Bachmayer, 1962), Palaeocarpilius rugifer Stoliczka, 1871 $y$. Necronectes sp. Además, P. rugifer es el indicio confirmado más reciente de esta especie, mientras que los otros dos taxones son las primeras muestras iranies en estos respectivos géneros. Este informe enriquece nuestro conocimiento sobre los conjuntos de decápodos del Mioceno en Irán, lo que contribuye a una mejor comprensión sobre los patrones migratorios de decápodos a lo largo de la vía marítima de Tetis.

Palabras clave: Brachyura, Mioceno temprano, Formación Qom, Isfahan, Irán central. 


\section{Introduction}

Number of studies on fossil decapod crustaceans of Iran were published in the last fifteen years. For such a geologically diverse country, this is, however, still insufficient and the knowledge on the decapod fossil record of Iran remains poor. The first report of fossil decapods was that by Förster and SeyedEmami (1982) on an erymid lobster from the Middle Jurassic of northern Iran. Cretaceous decapods were discussed by McCobb and Hairapetian (2009), Yazdi et al., (2009, 2010), Jagt et al., (2014), and Bahrami et al., (2020); the alleged lobster of uncertain affinities described by Feldmann et al., (2007) was later reinterpreted to be an isopod (Hyžný and Zorn, 2020). Cenozoic decapod occurrences from Iran include those from Eocene and Miocene strata. Eocene decapods were reported by Garassino et al., (2014) and Khodaverdi Hassan-vand et al. (2016). The first report on Miocene decapod crustaceans of Iran was an abstract by Torabi and Yazdi (2002), presenting a portunid crab from the Isfahan area. Much more attention was dedicated to Miocene decapod assemblages from the Mishan Formation (Vega et al., 2010a, 2012; Heidari et al., 2012; Hyžný et al., 2013; Yazdi et al., 2013; Key et al., 2017). The present study focuses on description of decapods from the lower Miocene of the Qom Formation exposed in the Isfahan area.

\section{Geological setting}

Oligo-Miocene deposits of the Qom Formation are located in the Sanandaj-Sirjan fore-arc basin, Urumieh-Dokhtar magmatic arc (UDMA) (intra-arc basin) and Central Iran back-arc basin. Deposition occurred during the final sea transgression of the Iranian Plate. The extensive shallow to open marine succession of the Qom Formation includes shallow-marine limestones and fossiliferous marl, with subordinate evaporites, and extends throughout Central Iran (Rahimpour-Bonab and Kalantarzadeh, 2005). The thickness of the Qom Formation varies from area to area. Active tectonics led to the formation of complicated local tectonic movements with erosional faces which influenced the lateral thickness in the Qom Formation and produced facies variations (Poroohan et al., 2009; Jalali and Feizi, 2010). Because of the major facies changes of the Qom Formation, no stratotype section has been introduced for it, but the Qom area (located approximately $100 \mathrm{~km}$ south of Teheran) is proposed as its type area (Rahimzadeh, 1994; Aghanabati, 2006; Mohammadi et al., 2011, 2013). The studied sections (Kuh-e-Donbeh, Bagher-Abad, and Vartun) are situated in the Isfahan area (Figure 1A) in the Isfahan-Sirjan fore-arc Basin.

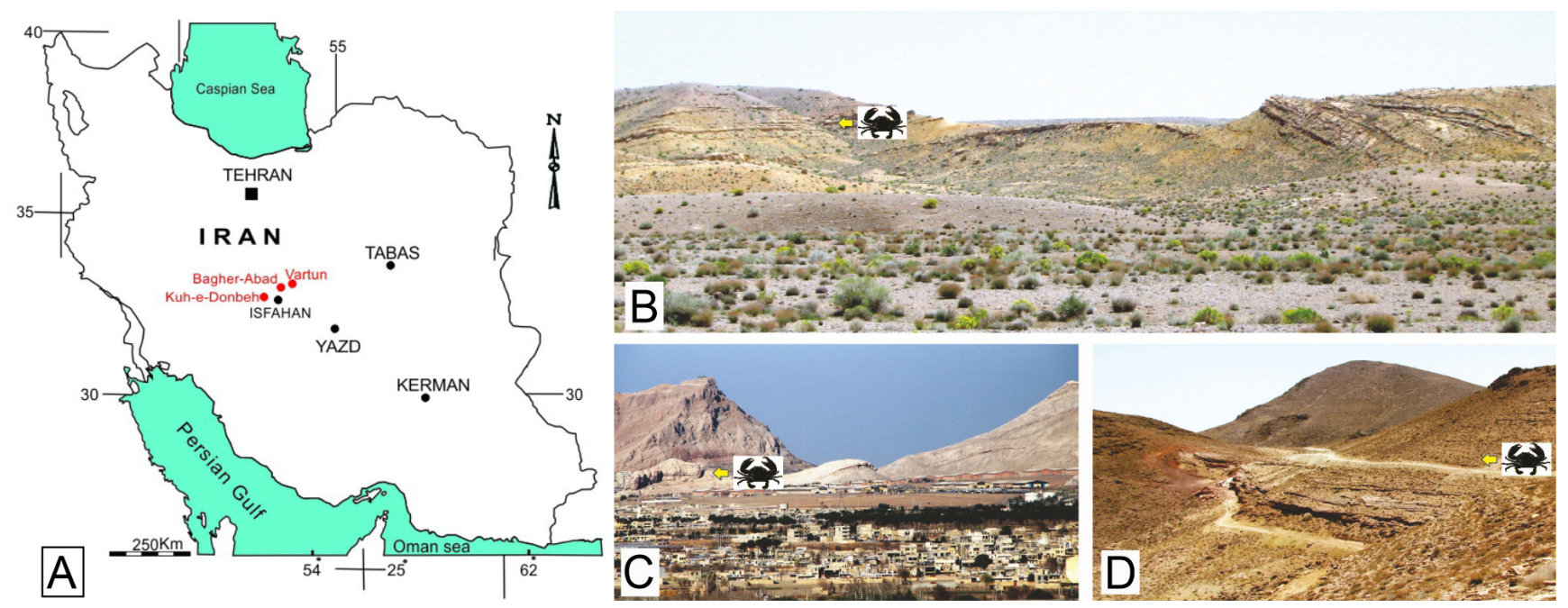

Figure 1 Study area with indication of decapod-bearing levels (indicated with icons and arrows). A. Geographical map of Iran with the position of the studied sections in Isfahan area. B. Vartun section, C. Kuh-e-Donbeh section, D. Bagher-Abad section. 


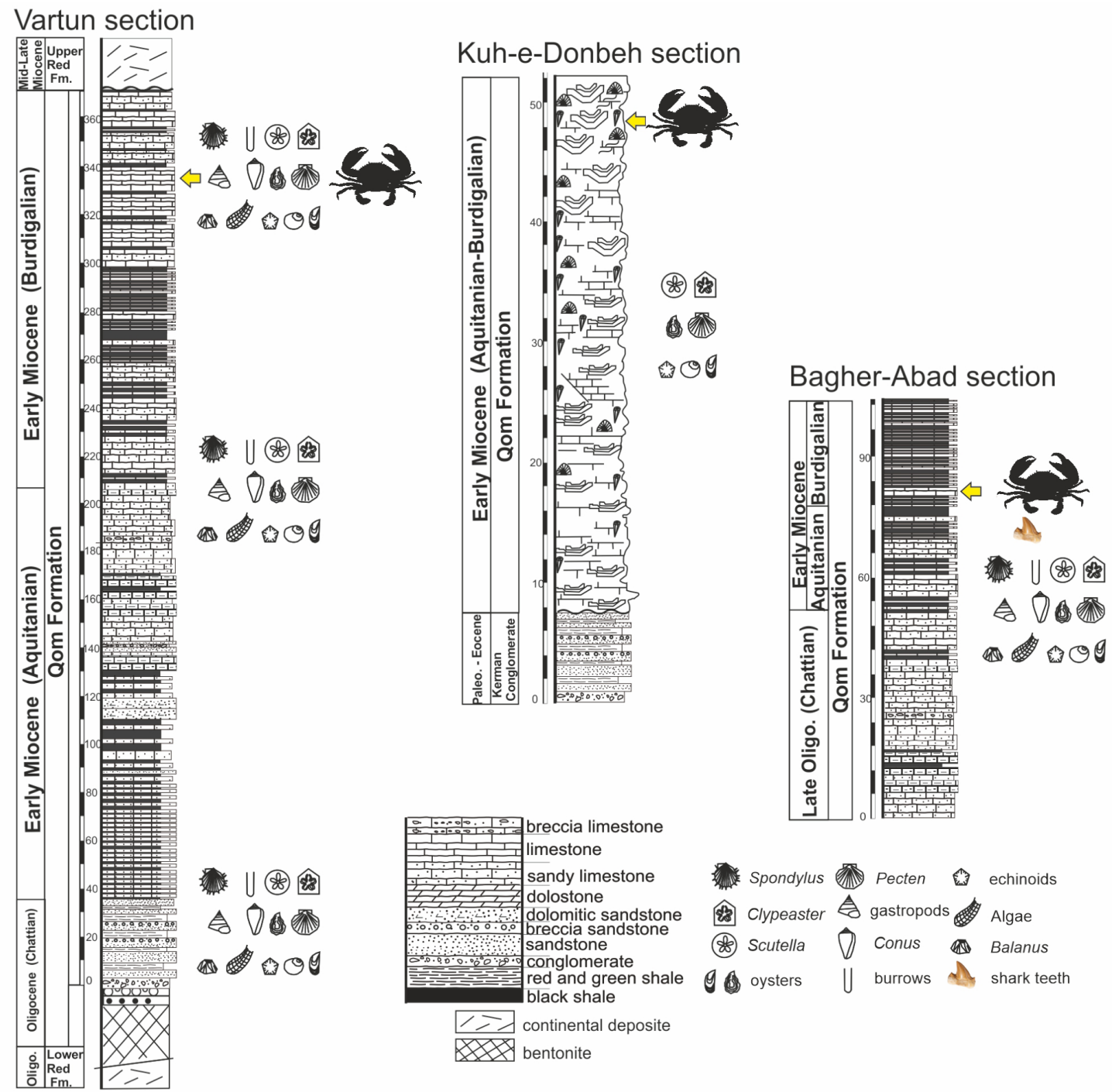

Figure 2 Lithostratigraphic columns of the studied sections with indication of decapod-bearing levels (indicated with icons and arrows).

The Kuh-e-Donbeh section (Figure 1C; GPS co-ordinates: $32^{\circ} 35^{\prime} 36^{\prime \prime} \mathrm{N}$; $51^{\circ} 34^{\prime} 57^{\prime \prime} \mathrm{E}$ ) is located in the residential part of the Isfahan city, along the Soffeh Mountain close to the Dorcheh district. The section exposes $50 \mathrm{~m}$ of reefal limestone with marl interbeds, and locally with colonial and solitary corals (Figure 2). Foraminifers Lepidocyclina sp., Amphistegina sp., Neoalveolina melocurdica, Peneroplis evolutus, Dentritina rangi, Meandropsina anahensis, Acervulina sp., and Archaias sp. indicate Aquitanian-Burdigalian age.

The Bagher-Abad section (Figure 1D; GPS co-ordinates: $32^{\circ} 59^{\prime} 50^{\prime \prime} \mathrm{N}$; $52^{\circ} 02^{\prime} 47^{\prime \prime} \mathrm{E}$ ) is located ca. $55 \mathrm{~km}$ north of Isfahan, along the
Isfahan-Ardestan road. The section was studied by Yazdi et al., (2012) and Nouradini et al., (2015). In the section, grey-yellow to yellow-white highly fossiliferous marls and fossiliferous argillaceous to sandy limestones are exposed (Figure 2). The fossils, among others, include coralline red algae (Lithophyllum sp., Lithothamnium sp.), molluscs (Spondylus sp., Turritella sp.), and echinoderms (Eucidaris sp., Clypeaster sp., scutellid echinoids). The fauna suggests a shallow, warm, marine environment of the inner neritic zone (Nouradini et al., 2015).

The Vartun section (Figure 1A; GPS co-ordinates: $32^{\circ} 55^{\prime} 51^{\prime \prime} \mathrm{N}$; $52^{\circ} 09^{\prime} 59^{\prime \prime} \mathrm{E}$ ) is located further along the Isfahan-Ardestan road. Here, 
thick prominent limestones (Figure 2), with minor intercalation of marly limestones with the occurrence of foraminifers Neoalveolina melocurdica, Peneroplis evolutus, Dentritina rangi, Meandropsina anahensis, Acervulina sp., and Archaias sp. are exposed. Faunal elements include also oyster shells, algal fragments, and other macrofossils. The foraminifers indicate Aquitanian-Burdigalian age (Pedramara et al., 2019).

\section{Material and methods}

From Burdigalian strata of studied sections, altogether seven fossil brachyuran crabs were examined (Figure 2): Kuh-e-Donbeh (1 specimen), Bagher-Abad (4 specimens), and Vartun Section (2 specimens). The specimens exhibit two modes of preservation: carapaces (either isolated or with attached appendages) and isolated cheliped elements. All studied specimens are fractured and/or eroded. Material was documented photographically. The specimens are deposited at Department of Geology, Faculty of Sciences, University of Isfahan, Iran (EUIC).

\section{Systematic palaeontology}

Order Decapoda Latreille, 1802

Section Eubrachyura de Saint Laurent, 1980

Subsection Heterotremata Guinot, 1977

Superfamily Carpilioidea Ortmann, 1893

Family Carpiliidae Ortmann, 1893

Genus Palaeocarpilius A. Milne-Edwards, 1862

Type species: Cancer macrochelus Desmarest, 1822,

by original designation.

Palaeocarpilius rugifer Stoliczka, 1871

Figures $3 \mathrm{~A}-3 \mathrm{E}$

1871 Palaeocarpilius rugifer - Stoliczka, p. 8, pl. 4, figs. 1-6, pl. 5, figs. 1-5.

?2009 Palaeocarpilius rugifer Stoliczka - Ralte, Lalchawimawii, Malsawma, Tiwari, p. 205, pl.1 fig. 12.
2010 Palaeocarpilius rugifer Stoliczka - Vega, Tiwari, Bajpai, p. 46, pl. 1, figs. 1-12.

Material: Female individual with preserved carapace, sternum, right (crusher) cheliped and portions of pereiopods 2 and 3 (EUIC 100) from the Kuh-e-Dondeh section; female individual with preserved carapace, pleon, and portions of both chelipeds, including left (cutter) claw (EUIC 101) from the Vartun section; female individual with preserved carapace, pleon, and portions of both chelipeds, including left (cutter), claw (EUIC 102) from the Vartun section; left (presumably cutter) cheliped propodus without fixed finger and with articulated (and broken) dactylus (EUIC 103) from the Bagher-Abad section; isolated crusher claw dactylus (EUIC 104) from the Bagher-Abad section.

Description: Carapace suboval transversely, widest at lower third, vaulted in both directions; front deflexed, poorly preserved; orbits presumably circular; anterolateral margins rounded, with seven blunt equally sized teeth; posterolateral margin slightly concave; posterior margin straight, approximately as wide as front. Carapace regions undefined, with short transverse ridges extending from last anterolateral tooth. Sternum subtriangular, sutures between respective sternites well-developed. Female pleon longitudinally ovate, somite 6 longest. Chelipeds robust, heterochelous, right claw (crusher) more robust, left claw (cutter) slenderer; merus and carpus of both chelae robust, propodus with at least four large blunt spines on its upper margin; right propodus subtriangular in outline, highest distally, fixed finger short; right dactylus strongly curved with large molariform teeth on occlusal surface; left propodus broadly elongate, fixed finger subtriangular, slender; right dactylus elongate, slender.

Remarks: The material, although incomplete and imperfectly preserved, clearly can be assigned to Palaeocarpilius A. Milne-Edwards, 1862 based on these characteristics: the carapace is suboval in outline, vaulted in both directions, and with undefined regions; anterolateral margins are adorned 


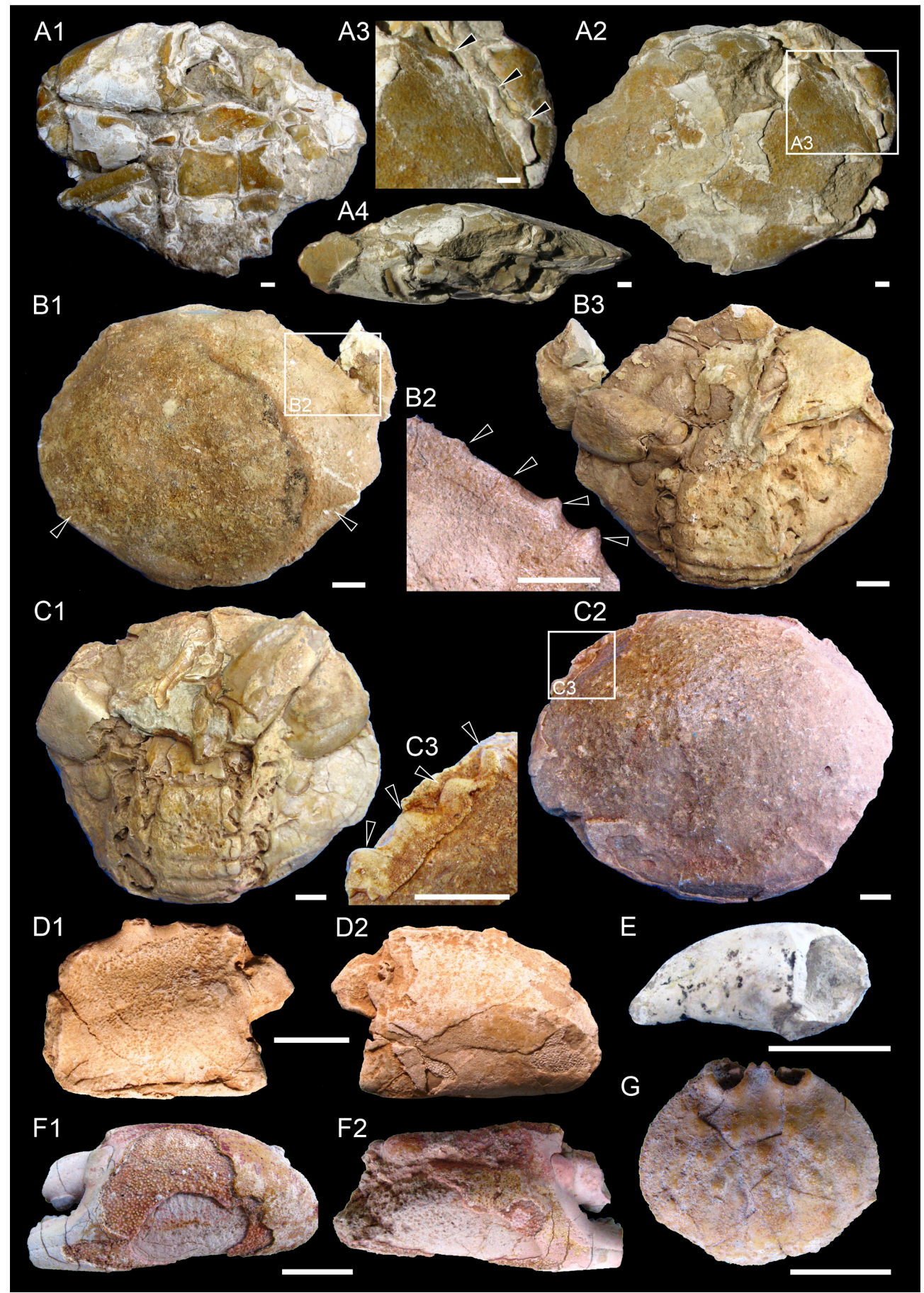

Figure 3 Decapod assemblage from the Burdigalian of the Qom Formation; Palaeocarpilius rugifer Stoliczka, 1871 (A-E), Necronectes sp. (F), and Mursia cf. lienharti (Bachmayer, 1962) (G). A. Female individual with preserved carapace, sternum, right (crusher) cheliped and portions of pereiopods 2 and 3 (EUIC 100) in ventral (A1), dorsal (A2), and frontal (A4) views. Note preserved anterolateral teeth (A3). B. Female individual with preserved carapace, pleon, and portions of both chelipeds, including left (cutter) claw (EUIC 101) in dorsal (B1) and ventral (B3) views. Note preserved anterolateral teeth (B2). C. Female individual with preserved carapace, pleon, and portions of both chelipeds, including left (cutter) claw (EUIC 102) in ventral (C1) and dorsal (C2) views. Note preserved anterolateral teeth (C3). D. Left (presumably cutter) cheliped propodus without fixed finger and with articulated (and broken) dactylus (EUIC 103) in inner (D1) and outer (D2) lateral views. E. Isolated crusher claw dactylus (EUIC 104) in lateral view. F. Left (cutter) chela consisting of propodus and dactylus, with both fingers broken at their bases (EUIC 105) in outer (F1) and inner (F2) lateral views. G. Dorsal carapace (EUIC 106). Scale bars equal $10 \mathrm{~mm}$. 
with blunt teeth; there is a well-developed ridge extending onto dorsal carapace from the last anterolateral tooth; chelipeds are strongly heterochelous, with the crusher claw having extremely high dactylus and short fixed finger; and the upper margin of the cheliped propodus is adorned with well-developed teeth (Schweitzer, 2003; Beschin and De Angeli, 2006). In Palaeocarpilius, the front is characteristically downturned and is bluntly triangular. One of the Iranian specimens indeed shows a downturned rostrum, although its morphology is not discernible due to poor preservation (Figures $3 \mathrm{~A}$ and 4). Importantly, the isolated cheliped propodus exhibits a row of several massive spines on its upper margin (Figure 3D). In the type species, P. macrochelus (Desmarest, 1822), a widespread European taxon known from the Eocene and Oligocene strata (Beschin and De Angeli, 2006; Hyžný and Zorn, 2020), there are eight round tubercles adorning the upper margin of the cheliped propodus, quite unlike four or five large spines as exhibited by the Iranian material. Such chelae are present in Oligocene species, $P$. aquitanicus A. Milne-Edwards, 1862 and P. rugifer Stoliczka, 1871, as depicted by Beschin and De Angeli (2006, pl. 2, figs. 2b, 2c) and Stoliczka (1871, pl. 5, figs. 1-3), respectively. Both species share the same number (7, excl. outer orbital tooth) of similarly shaped and sized anterolateral teeth. The Iranian material is assigned to $P$. rugifer based on the presence of more rugose carapace tuberculation; in $P$. aquitanicus, the tuberculation is finer (Beschin and De Angeli, 2006). Also, P. rugifer has been reported from the Oligocene of northeast India (Stoliczka, 1871; Vega et al., 2010b), which is rather close to studied Iranian localities.

Palaeocarpilius rugifer was previously reported from the Oligocene of India (Stoliczka, 1871; Vega et al., 2010b). The Miocene occurrence presented by Ralte et al. (2009) is questionable, as already commented upon by Vega et al. (2010b). Nevertheless, the Iranian material represents the confirmation of the extension of stratigraphic range of the species to the early Miocene.
Superfamily Calappoidea De Haan, 1833 [in De Haan, 1833-1850]

Family Calappidae De Haan, 1833 [in De Haan, 1833-1850]

Genus Mursia Desmarest, 1823

Type species: Mursia cristiata H. Milne Edwards, 1837, by subsequent monotypy.

Mursia cf. lienharti (Bachmayer, 1962)

Figure 3G

?1962 Calappa (?) lienharti - Bachmayer, p. 41, pl. 2, fig. 2.

?1984 Mursia lienharti (Bachmayer) - Müller, p. 68, pl. 39, figs. 1-6, pl. 40, figs. 1-3, 5-6.

?2021 Mursia lienharti (Bachmayer) - Hyžný, Dulai, p. 153, figs. 56.1-9.

Material: Complete dorsal carapace (EUIC 106) from the Bagher-Abad section.

Description: Carapace circular, convex in both directions. Front presumably trilobed, median lobe broken. Orbits deep, circular; supraorbital margin with two fissures. Orbitofrontal margin half of carapace width. Anterolateral margins arcuate, crenulated with unknown number of blunt lobes and lateral spine of unknown length. Posterolateral margins slightly concave, rimmed. Posterior margin approximately as wide as front. Regions undefined. Carapace surface covered with variously sized tubercles arranged in five subparallel longitudinal ridges, one median and two on branchial and hepatic regions.

Remarks: A single carapace does not present sufficient details for confident attribution on the species level. Carapace tuberculation is similar to that of early Miocene Mursia harnicari Hyžný and Schlögl, 2011, and middle Miocene M. lienharti (Bachmayer, 1962), both known from the circum-Mediterranean region. Unfortunately, the carapace surface of the Iranian material is abraded and its crenulation on the anterolateral margin is not discernible. Also, lateral spines are eroded and it is not clear how large they were 
originally. Nevertheless, their bases appear to be relatively small and therefore we classify the material as being closer to $M$. lienharti (possessing moderately sized lateral spines), rather than to $M$. harnicari (with elongate lateral spines). More and better-preserved material is needed to resolve the systematic placement of Iranian taxon.

Mursia lienharti is a widespread species to date, reported from the Oligocene of Germany (Polkowsky, 2014), the lower Miocene (Burdigalian) of Belgium (Müller in Janssen and Müller, 1984) and Italy (Beschin and De Angeli, 2012), and the middle Miocene of Austria (Bachmayer, 1962) and Hungary (Müller, 1984; Hyžný and Dulai, 2021). If the Iranian material is confirmed to represent this species, it would represent a major geographic extension further to the East.

Superfamily Portunoidea Rafinesque, 1815

Family Portunidae Rafinesque, 1815

Subfamily Necronectinae Glaessner, 1928

Genus Necronectes A. Milne-Edwards, 1881

Type species: Necronectes vidalianus A. Milne-Edwards, 1881, by original designation.

\section{Necronectes sp.}

Figure 3F

Material: Left (cutter) chela consisting of propodus and dactylus, with both fingers broken at their bases (EUIC 105), from the Bagher-Abad section.

Description: Left cheliped manus suboval in outline; lateral surfaces of both fingers with two longitudinal furrows with setal pores; occlusal surface of fixed finger with serial conical teeth of two sizes; occlusal surface of dactylus with molariform tooth.

Remarks: There are two closely related genera with very similar cheliped morphology as that shown in the studied material, Scylla de Haan, 1833 and Necronectes A. Milne-Edwards, 1881. A main difference between them is the number of anterolateral spines on the carapace (Schweitzer et al., 2006; Karasawa et al., 2008), a character which cannot be observed in the Iranian material. As for chelipeds, no comparative study between the two genera has been performed to date. However, Keenan et al., (1998) presented a revision of extant representatives of Scylla invariably showing spines in proximalmost and distalmost position of the propodal upper margin. These do not seem to be present in the chelipeds of Necronectes (Hyžný and Dulai, 2021, fig. 84). Because the Iranian material does not possess the respective spines, we assign it to Necronectes. The fragmentary nature of the specimen, however, prevents closer identification.

Torabi and Yazdi (2002) presented Necronectes iranensis as a new species from the Miocene of Central Iran. In the conference abstract, in which the taxon was presented, the authors failed to provide description or illustration of $\mathcal{N}$. iranensis, and Schweitzer et al. (2010) considered the name as a nomen nudum. We concur. It is possible that the new material presented herein is conspecific with $\mathcal{N}$. iranensis; unfortunately, without further data we are not able to compare both occurrences. Also, without a possibility of re-examination of $\mathcal{N}$. iranensis, it is difficult to confirm the attribution of the material presented by Torabi and Yazdi (2002) to Necronectes. Therefore, Necronectes sp. from Bagher-Abad is considered the first confirmed occurrence of the respective genus from the Miocene of Iran.

\section{Discussion}

The subduction and final collision of the African-Arabian and Iranian-Eurasian plates during early Miocene was accompanied by closure of the Tethyan Seaway (Harzhauser et al., 2007; Reuter et al., 2009). Consequently, Central-Iranian palaeogeography changed dramatically with the development of a volcanic arc, which separated a forearc from a back-arc basin during the Miocene.

The Oligo-Miocene deposits of the Qom Formation developed in the south-eastern margin of the Western Tethys Region (Figure 4). The faunas of this region are important for the interpretation of palaeobiogeography of the circum-Mediterranean region, including the proto-Mediterranean 
and Paratethys seas, and its connection with the Indian Ocean, as have been discussed by various scholars since the 1990s (Stöcklin and Setudehnia, 1991; Rögl, 1999; Seyrafian and Torabi, 2005; Harzhauser et al., 2007; Khaksar and Maghfori-Moghaddam, 2007; Daneshian and Ramezani Dana, 2007; Reuter et al., 2009; Mohammadi et al., 2011, 2013; Behforouzi and Safari, 2011; Yazdi et al., 2012).

Marine sedimentation of the Qom Formation began during the Oligocene and continued to the end of the early Miocene in the Isfahan-Sirjan fore-arc and in the Qom back-arc basins (Schuster and Wielandt, 1999). The timing of opening and closure of the Tethyan Seaway (especially in the fore-arc and back-arc basins) is still being debated. Bozorgnia (1966) believed that the Qom Sea (Qom back-arc basin) persisted from the Rupelian (early Oligocene) to the Burdigalian (late early Miocene). Schuster and Wielandt (1999) also mentioned that in both foreland basins (Sanandaj-Sirjan and Central Iran), the marine sedimentation began during the early Oligocene and continued until the end of the early Miocene. However, Berning et al. (2009), suggested that during the late Oligocene, the narrowing Tethyan Seaway formed a connection between the Eastern Tethys and the Western Tethys regions.

There are close faunal similarities between the Qom Basin and the proto-Mediterranean and the Paratethys. As for decapod crustaceans, genera reported herein are well-known from Cenozoic strata in the entire circum-Mediterranean region. Both Mursia and Necronectes were reported from the Oligo-Miocene of proto-Mediterranean (Müller, 1993; De Angeli and Garassino, 2006; De Angeli et al., 2019) and Paratethys (Müller, 1984; Hyžný, 2016; Hyžný and Dulai, 2021), whereas Palaeocarpilius aquitanicus, a morphologically close relative of $P$. rugifer, is known from the Oligocene of Italy and France (De Angeli and Garassino, 2006; De Angeli et al., 2019). Palaeocarpilius rugifer was reported also from the Oligocene of northeast India (Stoliczka, 1871; Vega et al., 2010b), an area occurring further eastward on the Tethyan Seaway back in the late Cenozoic. In a wider view, it is good to note that it is difficult to state whether any of these areas served as a place of origin of discussed taxa, which then spread to other regions. Representatives of Palaeocarpilius were widespread in the Western Tethys during the Eocene (Lörenthey and Beurlen, 1929; Vía Boada, 1969; Beschin and De Angeli, 2006), whereas the occurrences from Iran and India are younger (Oligocene). Similarly, Khodaverdi Hassan-vand et al. (2016) reported the co-occurrence of Retrocypoda almelai Vía Boada, 1959, from the middle Eocene of Catalonia and Iran, whereas the oldest occurrence of the species is known from the lower Eocene of France. Nevertheless, reports of other decapod taxa tell a different story: the oldest occurrences of ghost shrimps of the "karumba group", matching the lately erected genus Karumballichirus Poore, Dworschak, Robles, Mantelatto, and Felder, 2019, come from the Paleocene of Pakistan (Hyžný et al., 2016). As noted by Hyžný et al. (2016, p. 351), if the Pakistani occurrences were not known, the oldest occurrence of the group would be in the circum-Mediterranean area and would match the "Go East!" scenario of Harzhauser et al., (2007) or the concept of hoping biodiversity hotspots of Renema et al., (2008). However, Cenozoic decapod assemblages of Eastern and Western Tethyan regions show a relative homogeneity at the genus level, as already suggested by Merle $e t$ al., (2014) for gastropods. More research is needed

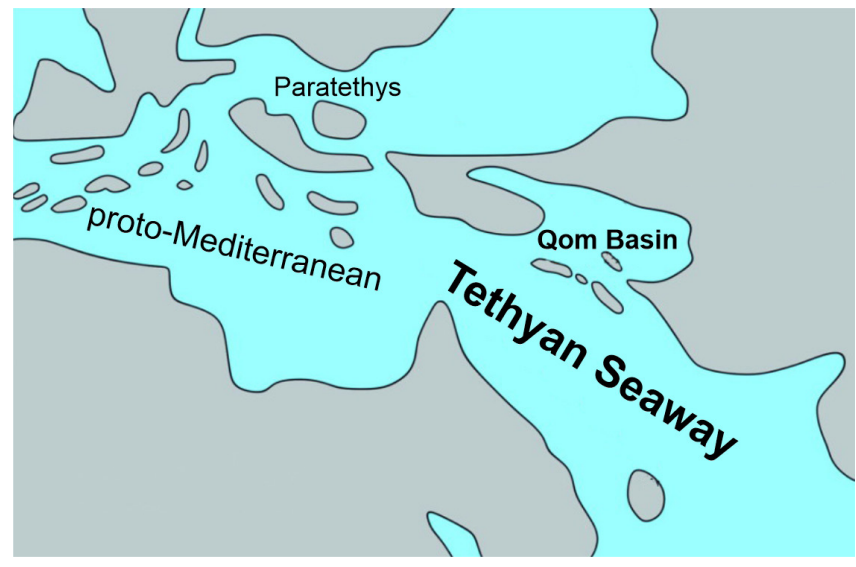

Figure 4 Palaeogeographic map of the Tethyan Seaway with indication of the Qom Basin (after Harzhauser and Piller, 2007; Reuter et al., 2009). 
to resolve the migratory routes of decapod crustaceans along the Tethyan Seaway, which might change throughout several tens of million years. Fossils from the Qom Basin, being positioned in the middle between Eastern and Western Tethyan regions, are of great importance in this research.

\section{Conclusions}

From the lower Miocene (Burdigalian) of the Qom Formation, exposed in three sections in Central Iran, a decapod crustacean assemblage is described. Based on moderately-well preserved specimens, three taxa were identified, including Mursia cf. lienharti, Palaeocarpilius rugifer, and Necronectes sp. The occurrence of $P$. rugifer represents the youngest confirmed occurrence of the species, whereas other two taxa represent the first Iranian occurrences of the respective genera. This report enriches our knowledge on Miocene decapod assemblages of Iran, helping to better understand the migratory patterns along the Tethyan Seaway.

\section{Acknowledgements}

The authors would like to thank the University of Isfahan for providing laboratorial and field trip logistics. Francisco J. Vega (Universidad Nacional Autónoma de México, Mexico) provided photos of comparative material. Constructive comments of reviewers Hiroaki Karasawa (Mizunami Fossil Museum, Gifu, Japan) and Francisco J. Vega improved the manuscript.

\section{References}

Aghanabati, A., 2006, Geology of Iran: Tehran, Ministry of Industry and Mine, Geological Survey of Iran, 586 p.

Bachmayer, F., 1962, Die Calappiden (Crustacea, Decapoda) aus den tortonischen
Ablagerungen des Wiener Beckens: Annalen des Naturhistorischen Museums in Wien, 65, 39-46.

Bahrami, A., Yazdi, M., González-León, O., Serrano-Sánchez, M.L., Vega, J.V., 2020, Crustacea (Isopoda, Anomura, Brachyura) from the Cretaceous of Soh area (NW Isfahan) Central Iran: Boletín de la Sociedad Geológica Mexicana, 72(2), 1-14. https:// doi.org/10.18268/bsgm2020v72n2a271019

Behforouzi, E., Safari, A., 2011, Biostratigraphy and paleoecology of the Qom Formation in Chenar area (northwestern Kashan), Iran: Revista Mexicana de Ciencias Geológicas, 28, 555-565. https://doi.org/10.1007/ s13146-017-0415-9

Berning, B., Reuter, M., Piller, W.E., Harzhauser, M., Kroh, A., 2009, Larger foraminifera as a substratum for encrusting bryozoans (Late Oligocene, Tethyan Seaway, Iran): Facies, 55, 227-241. https://doi.org/10.1007/ s10347-008-0169-x

Beschin, C., De Angeli, A., 2006, II genere Palaeocarpilius A. Milne Edwards, 1862 (Decapoda, Brachyura, Carpiliidae) nel terziario del Vicentino (Italia settentrionale): Studi e Ricerche - Associazione Amici del Museo - Museo Civico "G. Zannato", 13, 11-23.

Beschin, C., De Angeli, A., 2012, Crostacei decapodi del Veneto occidentale (Vicenza, Italia settentrionale): Studi e Ricerche Associazione Amici del Museo - Museo Civico "G. Zannato", 19, 5-14.

Bozorgnia, F., 1966, Qom Formation stratigraphy of the Central basin of Iran and its intercontinental position: Iranian Petroleum Institute Bulletin, 24, 69-75.

Daneshian, J., Ramezani Dana, L., 2007, Early Miocene benthic foraminifera and biostratigraphy of the Qom Formation, Deh Namak, central Iran: Journal of Asian Earth Science, 29, 844-858. https://doi. org/10.1016/j.jseaes.2006.06.003

De Angeli, A., Garassino, A., 2006, Catalog and bibliography of the fossil Stomatopoda and 
Decapoda from Italy: Memorie della Società Italiana di Scienze Naturali e del Museo Civico di Storia Naturale di Milano, 35(1), 3-95.

De Angeli, A., Garassino, A., Pasini, G., 2019, Catalog and bibliography of fossil Stomatopoda and Decapoda from Italy (2007-2018): Memorie della Società Italiana di Scienze Naturali e del Museo Civico di Storia Naturale di Milano, 45, 3-86.

De Haan, W., 1833-1850, Crustacea, in Siebold, P.F. von, (ed.), Fauna Japonica, sive Descriptio animalium, quae in itinere per Japoniam, jussu et auspiciis superiorum, qui summum in India Batavia imperium tenet, suscepto, annis 1823-1830 collegit, notis, observationibus a adumbrationibus illustravit: Lugduni Batavorum [Leiden], J. Müller et Co, 1-8. https://doi.org/10.5962/bhl.title.124951

Desmarest, A.G., 1822, Histoire naturelle des crustacés fossiles. Les crustacés proprement dits: Paris, F.G. Levrault, 67-154. https:// doi.org/10.5962/bhl.title.9102

Desmarest, A.G., 1823, Crustacés Malacostracés, in Levrault, F.-G. (ed.), Dictionnaire des Sciences Naturelles, dans lequel on traite méthodiquement des différens êtres de la nature, considérés soit en eux-mêmes, d'après l'état actuel de nos connoissances, soit relativement a l'utilité qu'en peuvent retirer la médicine, l'agriculture, le commerce et les arts: Paris, F.G. Levrault, 28, 138-425.

Feldmann, R.M., Kolahdouz, A., Biranvand, B., Schweigert, G., 2007, A new family, genus, and species of lobster (Decapoda: Achelata) from the Gadvan Formation (Early Cretaceous) of Iran: Journal of Paleontology, 81, 405-407. https://doi. org/10.1666/0022-3360(2007)81 [405:anfga s]2.0.co;2

Förster, R., Seyed-Emami, K., 1982, First occurence of Eryma bedelta (Quenstedt) (Crustacea, Decapoda) from the Aalenian of Iran: Mitteilungen der Bayerischen Staatssammlung für Paläontologie und Historische Geologie, 22, 41-45.
Garassino, A., Bahrami, A., Yazdi, M., Vega, F.J., 2014, Report on decapod crustaceans from the Eocene of Zagros Basin, Iran: Neues Jahrbuch für Geologie und Paläontologie - Abhandlungen, 274, 43-54. https://doi. org/10.1127/njgpa/2014/0442

Glaessner, M.F., 1928, Die Dekapodenfauna des österreichischen Jungtertiärs: Jahrbuch der Geologischen Bundesanstalt Wien, 78, 161-219.

Guinot, D., 1977, Propositions pour une nouvelle classification des Crustacés Décapodes Brachyoures: Comptes rendus hebdomadaires des séances de l'Académie des sciences, série D, 285, 1049-1052.

Harzhauser, M., Kroh, A., Mandic, O., Piller, W.E., Göhlich, U., Reuter, M., Berning, B., 2007, Biogeographic responses to geodynamics: a key study all around the Oligo-Miocene Tethyan Seaway: Zoologischer Anzeiger, 246, 241-256. https://doi.org/10.1016/j. jcz.2007.05.001

Harzhauser, M., Piller, W.E., 2007, Benchmark data of a changing sea and events in the Central Paratethys during the Miocene: Palaeogeography, Palaeoclimatology, Palaeoecology, 253, 8-31. https://doi. org/10.1016/j.palaeo.2007.03.031

Heidari, A., Feldmann, R.M., Moussavi-Harami, R., 2012, Miocene decapod crustacean from the Guri Member of the Mishan Formation, Bandar-Abbas, Southern Iran: Bulletin of the Mizunami Fossil Museum, 38, 1-7. https:// doi.org/10.1007/s12594-014-0112-4

Hyžný, M., 2016, Diversity and distribution of the Oligocene and Miocene decapod crustaceans (Crustacea: Malacostraca) of the Western and Central Paratethys: Geologica Carpathica, 67, 471-494. https://doi. org/10.1515/geoca-2016-0030

Hyžný, M., Dulai, A., 2021, Badenian decapods of Hungary: GeoLitera Publishing House, Institute of Geosciences, University of Szeged, Hungary, 300 p.

Hyžný, M., Schlögl, J., 2011, An early Miocene deep-water decapod crustacean faunule from 
the Vienna basin (Western Carpathians, Slovakia):Palaeontology,54,323-349.https:// doi.org/10.1111/j.1475-4983.2011.01033.x

Hyžný, M., Zorn, I., 2020, A Catalogue of the Fossil Decapod Crustaceans in the Collections of the Geological Survey of Austria in Vienna: Abhandlungen der Geologischen Bundesanstalt, 74, 1-111.

Hyžný, M., Bahrami, A., Klompmaker, A.A., Yazdi, M., Portell, R.W., Neumann, Ch., 2013, The fossil record of Glypturus (Decapoda: Axiidea: Callianassidae) revisited with additional observations and description of a new species: Swiss Journal of Palaeontology 132, 129-139. https://doi. org/10.1007/s13358-013-0060-4

Hyžný, M., Charbonnier, S., Merle, D., Ahmed Lashari, R., Bartolini, A., Métais, G., 2016, New Early Cenozoic ghost shrimps (Decapoda, Axiidea, Callianassidae) from Pakistan and their palaeobiogeographic implications: Geodiversitas, 38, 341-353. https://doi.org/10.5252/g2016n3a2

Jagt, J.W.M., Van Bakel, B.W.M., Fraaije, R.H.B., Neumann, G., 2014, New data on midCretaceous dromioid crabs (Crustacea, Decapoda, Brachyura) from northwest Germany and southwest Iran. In: Fraaije, R.H.B., Hyžný, M., Jagt, J.W.M., Krobicki, M. \& Van Bakel, B.W.M. (eds.), Proceedings of the 5th Symposium on Mesozoic and Cenozoic Decapod Crustaceans, Krakow, Poland, 2013: A tribute to Pál Mihály Müller: Scripta Geologica, 147, 35-47.

Jalali, M., Feizi, M., 2010, Introduction of Miocene deposits turbidities in the SavehTakab area (NW of central Iran basin): The First International Applied Geological Congress, Department of Geology, Islamic Azad University-Mashad Branch, Iran, 26-28.

Janssen, A.W., Müller, P., 1984, Miocene Decapoda and Mollusca from Ramsel (province of Antwerpen, Belgium), with a new crab genus and a new cephalopod species: Scripta Geologica, 75, 1-26.
Karasawa, H., Schweitzer, G.E., Feldmann, R.M., 2008, Revision of Portunoidea Rafinesque, 1815 (Decapoda: Brachyura) with emphasis on the fossil genera and families: Journal of Crustacean Biology, 28, 82-127. https://doi. org/10.1651/07-2882r. 1

Keenan, G.P., Davie, P.J.F., Mann, D.L., 1998, A revision of the genus Scylla De Haan, 1833 (Crustacea: Decapoda: Brachyura: Portunidae): Raffles Bulletin of Zoology, 46, 217-245.

Key, M.M. Jr., Hyžný, M., Khosravi, E., Hudáčková, N., Robin, N., Ataabadi, M.M., 2017, Bryozoan epibiosis on fossil crabs: a rare occurrence from the Miocene of Iran: Palaios, 32, 491-505. https://doi.org/10.2110/ palo.2017.040

Khaksar, K., Maghfori-Moghaddam, I., 2007, Paleontological study of the echinoderms in the Qom Formation (Central Iran): Islamic Azad University, Earth Science Researches, 11, 57-79.

Khodaverdi Hassan-vand, M., Bahrami, A., Yazdi, M., Ossó, À., Safari, A., Martínez, J.L., Vega, FJ., 2016, Occurrence of Retrocypoda almelai Via Boada, 1959 (Decapoda: Retroplumidae) in the Eocene of Central Iran: Paleontología Mexicana, 5, 21-31.

Latreille, P.A., 1802, Histoire naturelle, générale et particulière des Crustacés et des Insectes. Ouvrage faisant suite à l'histoire naturelle générale et particulière, composée par Leclerc de Buffon, et rédigée par C.S. Sonnini, membre de plusieurs Sociétés savantes: Paris, Dufart, 476 p. https://doi.org/10.5962/bhl. title. 15764

Lőrenthey, E., Beurlen, K., 1929, Die fossilen Dekapoden der Länder der Ungarischen Krone: Geologica Hungarica, Series Palaeontologica, 3, 1-421.

McCobb, L.M.E., Hairapetian, V., 2009, A new lobster Paraclytia valashtensis (Crustacea, Decapoda, Nephropidae) from the Late Cretaceous of the central Alborz Range, Iran: Paläontologische Zeitschrift, 83, 419-430. https://doi.org/10.1007/s12542-009-0033-5 
Merle, D., Pacaud, J.-M, Métais, G., Bartolini, A., Lashari, R. A., Brohi, I. A., Solangi, S. H., Marivaux, L., Welcomme, J.L., 2014. Volutidae (Mollusca: Gastropoda) of the Lakhra Formation (Earliest Eocene, Sindh, Pakistan): systematics, biostratigraphy and paleobiogeography: Zootaxa, 3826, 101-138. https://doi.org/10.11646/zootaxa.3826.1.3

Milne-Edwards, A., 1862, Monographie des Crustacés fossiles de la famille des Cancériens: Annales des Sciences Naturelles, Botanique, 4e série, 18, 31-85, Paris. https:// doi.org/10.5962/bhl.title.10335

Milne-Edwards, A., 1881, Note sur quelques Crustacés fossils des environs de Biarritz: Annales des Sciences Géologiques, Paris, 11(2), 1-8.

Milne Edwards, H., 1834-1840, Histoire naturelle des Crustacés, comprenant l'anatomie, la physiologie et la classification de ces animaux. Librairie Encyclopédique de Roret. Vol. 1-3: Paris, Roret, 1: 468 p.; 2: 532 p.; 3: 638 p. https://doi.org/10.5962/bhl.title.39738

Mohammadi, E., Safari, A., Vaziri-Moghaddam, H., Vaziri, M.R., Ghaedi, M., 2011, Microfacies analysis and paleoenvironmental interpretation of the Qom Formation, south of the Kashan, Central Iran: Carbonates and Evaporites, 26, 255-271. https://doi. org/10.1007/s13146-011-0059-0

Mohammadi, E., Hasanzadeh-Dastgerdi, M., Ghaedi, M., Dehghan, R., Safari, A., VaziriMoghaddam, H., Baizidi, C., Vaziri, M., Sfidari, E., 2013, The Tethyan Seaway Iranian Plate Oligo-Miocene deposits (the Qom Formation): distribution of Rupelian (Early Oligocene) and evaporate deposits as evidences for timing and trending of opening and closure of the Tethyan Seaway: Carbonates and Evaporites, 28, 321-345. https://doi.org/10.1007/ s13146-012-0120-7

Müller, P., 1984, Decapod Crustacea of the Badenian: Geologica Hungarica, Series Palaeontologica, 42, 3-317. https://doi. org/10.2307/1548660
Müller, P., 1993, Neogene decapod crustaceans from Catalonia: Scripta Musei Geologici Seminarii Barcinonensis, 225, 1-39.

Nouradini, M., Azami, S.H., Hamad, M., Yazdi, M., Ashouri, A., 2015, Foraminiferal paleoecology and paleoenvironmental reconstructions of the lower Miocene deposits of the Qom formation in Northeastern Isfahan, Gentral Iran: Boletín de la Sociedad Geológica Mexicana, 67, 59-73. https://doi. org/10.18268/bsgm2015v67nla5

Ortmann, A., 1893, Die Decapoden-Krebse des Strassburger Museums. VI. Theil. Abtheilung: Brachyura (Brachyura genuina Boas) 1. Unterabtheilung: Majoidea und Cancroidea, 1. Section Portuninea. Zoologische Jahrbücher, Abtheilung für Systematik, Geographie und Biologie der Thiere, 7, 23-88. https://doi.org/10.5962/ bhl.part.24064

Pedramara, A., Zágoršek, K., Bitner, M.A., Yazdi, M., Bahrami, A., Maleki, Z., 2019, Bryozoans and brachiopods from the Lower Miocene deposits of the Qom Formation in North-East Isfahan (Central Iran): Neues Jahrbuch für Geologie und Paläontologie Abhandlungen, 294, 229-250. https://doi. org/10.1127/njgpa/2019/0852

Polkowsky, S., 2014, Krebse und Krabben aus nord-deutschen Geschieben: Tassados, 2, $1-442$.

Poore, G.C.B., Dworschak, P.C.D., Robles, R., Mantelatto, F.L., Felder, D.L., 2019, A new classification of Callianassidae and related families (Crustacea: Decapoda: Axiidea) derived from a molecular phylogeny with morphological support: Memoirs of Museum Victoria, 78, 73-146. https://doi. org/10.24199/j.mmv.2019.78.05

Poroohan, N., Teimoornegad, K., Mohajjel, M., 2009, Geometry and kinematics of QomZefreh Fault System and its Significance in Transpresssion Tectonics, in Proceedings of the Third IASME-WSEAS International Conference on Geology and Seismology, 53-57. 
Rafinesque, G.S., 1815, Analyse de la Nature, ou Tableau de l'Univers et des Corps Organisés.: Palermo, L'Imprimerie de Jean Barravecchia, 224p. https://doi.org/10.5962/bhl. title. 106607

Rahimpour-Bonab, H., Kalantarzadeh, Z., 2005, Origin of secondary potash deposits: a case from Miocene evaporates of NW Central Iran: Journal of Asian Earth Sciences, 25, 157-166. https://doi.org/10.1016/j. jseaes.2004.02.004

Rahimzadeh, F., 1994, Geological map of the Moghan: Geological Survey of Iran, scale 1: 250,000.

Ralte, V.Z., Lalchawimawii, M., Malsawma, J., Tiwari, R.P., 2009, Decapod fossils from the Bhuban Formation, Surma Group, Aizawl, Mizoram : Earth Science India, 2, 196-210.

Renema, W., Bellwood, D.R., Braga, J.C., Bromfield, K., Hall, R., Johnson, K.G., Lunt, P., Meyer, C.P., McMonagle, L.B., Morley, R.J., O'Rea, A., Todd, J.A., Wesselingh, F.P., Wilson, M.E.J., Pandolfi, J.M., 2008, Hopping hotspots: global shifts in marine biodiversity: Science, 321, 654-657.

Reuter, M., Piller, W.E., Harzhauser, M., Mandic, O., Berning, B., Rögl, F., Kroh, A., Aubry, M.P., Wielandt-Schuster, U., Hamedani, A., 2009, The Oligo-/Miocene Qom Formation (Iran): evidence for an early Burdigalian restriction of Tethyan Seaway and closure of its Iranian gateways: International Journal of Earth Science, 98, 627-650. https://doi. org/10.1126/science.1155674

Rögl, F., 1999, Mediterranean and Paratethys. Facts and hypotheses of an Oligocene to Miocene paleogeography (short overview): Geologica Carpathica, 50, 339-349. https:/ / doi.org/10.1017/cbo9780511542329.002

Saint Laurent, M. de, 1980, Sur la classification et la phylogénie des Crustacés Décapodes Brachyoures. I. Podotremata Guinot, 1977 et Eubrachyura sect. nov: Comptes rendus hebdomadaires des Séances de l'Académie des Sciences, 290, 1265-1268.
Seyrafian, A., Torabi, H., 2005, Petrofacies and sequence stratigraphy of the Qom Formation (Late Oligocene- Early Miocene), north of Nain, Southern trend of the Central Iranian Basin: Carbonates and Evaporites, 20, 82-90. https://doi.org/10.1007/bf03175451

Schuster, F., Wielandt, U., 1999, Oligocene and Early Miocene coral faunas from Iran: palaeoecology and palaeobiogeography: International Journal of Earth Sciences, 88, 571-581. https://doi.org/10.1007/ s005310050285

Schweitzer, C.E., 2003, Utility of proxy characters for classification of fossils: an example from the fossil Xanthoidea (Crustacea: Decapoda: Brachyura): Journal of Paleontology, 77, 1107-1128. https://doi.org/10.1666/00223360(2003)077\%3C1 107:uopcfc\%3E2.0. co;2

Schweitzer, G.E., Iturralde-Vinent, M., Hetler, J.L., Velez-Juarbe, J., 2006, Oligocene and Miocene decapods (Thalassinoidea and Brachyura) from the Caribbean: Annals of Carnegie Museum, 75, 111-136. https://doi. org/10.2992/0097-4463(2006)75[111:oamd ta] 2.0.co;2

Schweitzer, G.E., Feldmann, R.M., Garassino, A., Karasawa, H., Schweigert, G., 2010, Systematic list of fossil decapod crustacean species: Crustaceana Monographs, 10, 1-230. https://doi.org/10.1163/ ej.9789004178915.i-222

Stöcklin, J., Setudehnia A., 1991, Stratigraphic Lexicon of Iran, Report No. 18: Tehran, Iran, Geological Survey of Iran, 376 p.

Stoliczka, F., 1871, Observations of fossil crabs from Tertiary deposits in Sind and Kutch: Memoirs of the Geological Survey of India, Palaeontologica Indica, 14(1), 1-16.

Torabi, H., Yazdi, M., 2002, First report on Miocene decapod fauna (Crustacea) from central Iran, a preliminary study on their environmental and ecological factors: Geological Society of Australia Abstracts, 68, 156. 
Vega, F.J., Gholamalian, H., Bahrami, A., 2010a, First record of Miocene crustaceans from Hormozgan Province, Southern Iran: Paläontologische Zeitschrift, 84, 485-493. https://doi.org/10.1007/ s 12542-010-0062-0

Vega, F.J., Tiwari, J.K., Bajpai, S., 2010b, Additions to Palaeocarpilius rugifer Stoliczka from the Oligocene of Kutch, western India: Bulletin of the Mizunami Fossil Museum, 36, 45-49.

Vega, F.J., Gholamalian, H., Hassani, M.J., Sajadi, S.-H., Schaaf, P., 2012, Miocene Crustacea from northern Bandar Abbas, South Iran: Neues Jahrbuch für Geologie und Paläontologie, Abhandlungen, 265, 221-234. https://doi. org/10.1127/0077-7749/2012/0247

Vía Boada, L., 1959, Decápodos fósiles del Eoceno español: Boletin del Instituto Geológico y Minero de España, 70, 1-72.

Vía Boada, L., 1969, Crustáceos Decápodos del Eoceno Español: Pirineos, Instituto Geológico Español, (91-94), 479 p.
Yazdi, M., Bahrami, A., Vega, F.J., 2009, Albian decapod Crustacea from Southwest Isfahan, Central Iran-Kolah-Qazi area: Bulletin of the Mizunami Fossil Museum, 35, 71-77. https:// doi.org/10.1127/njgpa/2017/0631

Yazdi, M., Bahrami, A., Vega, F.J., 2010, Additions to Albian (Cretaceous) Crustacea from Iran: Boletín de la Sociedad Geológica Mexicana, 62, 207-211. https://doi.org/10.18268/ bsgm2010v62n2al

Yazdi, M., Shirazi Parvanenejad, M., Rahiminejad, A.H., Motavalipoor, R., 2012, Paleobathymetry and paleoecology of colonial corals from the Oligocene-Early Miocene (?) Qom Formation (Dizlu area, central Iran): Carbonates and Evaporites, 27, 395-405. https://doi.org/10.1007/s13146-012-0122-5

Yazdi, M., Bahrami, A., Abbasi, P., Sadeghi, R., Vega, F.J., 2013, Miocene brachyuran Crustacea from Konar-Takhteh and Ahram sections, southwestern Iran: Boletín de la Sociedad Geológica Mexicana, 65, 225-233. https://doi.org/10.18268/ bsgm2013v65n2a4 